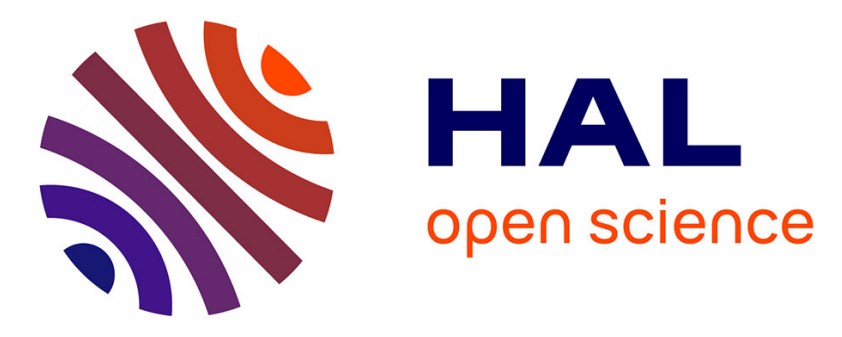

\title{
Dry direct-seeded rice as an alternative to transplanted-flooded rice in Central China
}

Hongyan Liu, Saddam Hussain, Manman Zheng, Shaobing Peng, Jianliang Huang, Kehui Cui, Lixiao Nie

\section{- To cite this version:}

Hongyan Liu, Saddam Hussain, Manman Zheng, Shaobing Peng, Jianliang Huang, et al.. Dry directseeded rice as an alternative to transplanted-flooded rice in Central China. Agronomy for Sustainable Development, 2015, 35 (1), pp.285-294. 10.1007/s13593-014-0239-0 . hal-01284261

\section{HAL Id: hal-01284261 \\ https://hal.science/hal-01284261}

Submitted on 7 Mar 2016

HAL is a multi-disciplinary open access archive for the deposit and dissemination of scientific research documents, whether they are published or not. The documents may come from teaching and research institutions in France or abroad, or from public or private research centers.
L'archive ouverte pluridisciplinaire HAL, est destinée au dépôt et à la diffusion de documents scientifiques de niveau recherche, publiés ou non, émanant des établissements d'enseignement et de recherche français ou étrangers, des laboratoires publics ou privés. 


\title{
Dry direct-seeded rice as an alternative to transplanted-flooded rice in Central China
}

\author{
Hongyan Liu • Saddam Hussain • Manman Zheng • \\ Shaobing Peng • Jianliang Huang • Kehui Cui • \\ Lixiao Nie
}

Accepted: 24 June 2014 / Published online: 18 July 2014

(C) INRA and Springer-Verlag France 2014

\begin{abstract}
Dry direct-seeded rice is an alternative cropping technique that should require less water and labor than classical transplanted-flooded rice. Here, we studied growth, yield and resource use efficiency of rice cultivation in Central China, in 2012 and 2013. We compared dry direct-seeded rice and transplanted-flooded rice. For dry direct-seeded rice, we maintained aerobic conditions up to five-leaf stage followed by anaerobic conditions until maturity. We grew three rice cultivars: Lvhan1, Huanghuazhan, and Yangliangyou6. We measured grain yield, yield components, water consumed, water productivity and nitrogen use efficiency for grain production (NUEg). Our results show that grain yield of dry direct-seeded rice, of $9.01 \mathrm{Mg} / \mathrm{ha}$, is identical to grain yield of transplanted-flooded rice, across cultivars and for both years. The grain yield of dry direct-seeded rice is mainly controlled by the panicle number. Moreover, dry direct-seeded rice uses $15.3 \%$ less water than transplantedflooded rice. Dry direct-seeded rice increased the grain nitrogen use efficiency by $20.3 \%$ in 2012 and $11.2 \%$ in 2013.
\end{abstract}

Keywords Water and labor shortage · Dry direct-seeded rice Transplanted-flooded rice $\cdot$ Grain yield $\cdot$ Nitrogen use efficiency (NUE) · Water productivity (WP)

H. Liu $\cdot$ S. Hussain $\cdot$ M. Zheng $\cdot$ S. Peng $\cdot$ J. Huang $\cdot$ K. Cui $\cdot$

L. Nie $(\bowtie)$

National Key Laboratory of Crop Genetic Improvement, MOA Key

Laboratory of Crop Ecophysiology and Farming System in the

Middle Reaches of the Yangtze River, College of Plant Science and

Technology, Huazhong Agricultural University, Wuhan,

Hubei 430070, China

e-mail: nielixiao@mail.hzau.edu.cn

\section{Introduction}

Rice (Oryza sativa L.), a staple food for more than half of the world's population, is grown in more than 95 countries across the globe (Coats 2003; IRRI 2002). China is the main producer of rice, contributing more than $28 \%$ of total global rice production. Therefore, stability of rice production in China plays a key role in the world's food security (FAOSTAT 2011). In China, traditional transplanted flooded rice is the major production system and nearly $95 \%$ of the rice is grown under such conditions with prolonged periods of flooding (Peng et al. 2009). Transplanted-flooded rice consumes more than $50 \%$ of the fresh water resources in China that are diverted for human uses (Cai and Chen 2000). However, in recent years, depleting water resources governed by climate change and labor shortage are threatening the sustainability and productivity of transplanted-flooded rice. Tuong and Bouman (2003) reported that, in Asia, 39 million ha of irrigated rice may suffer from "physical water scarcity" or "economic water scarcity" by 2025. Presently, per capita fresh water availability in China is among the lowest in Asia (Liu and Diamond 2005). Compared with other cereal crops such as wheat and maize, transplanted-flooded rice consumes two or three times more water. Transplanted-flooded rice leads to high losses of water through puddling, surface evaporation and percolation (Farooq et al. 2011). Chauhan and Opeña (2012) reported that puddling in transplanted-flooded rice systems consumes up to $30 \%$ of the total rice water requirement. Although, puddling is favorable in rice-rice cropping systems, as it reduces soil permeability, creates hardpans and reduces water losses through percolation. Nonetheless, repeated puddling operations negatively affect the following non-rice upland crop in rotation (McDonald et al. 2006) by dismantling soil aggregates, reducing permeability in subsurface layers, and forming hardpans at shallow depths (Sharma et al. 2003). 
Taking the advantages of saving water and labor and increasing system productivity, dry direct-seeded rice has been believed to be an optimal option for rice production (Kumar and Ladha 2011). Dry direct-seeded rice refers to the process of establishing the crop from seeds sown in the nonpuddled and unsaturated soil (Fig. 1a, left); in contrast, the seedlings from nursery are transplanted in the puddle soil in transplanted-flooded rice (Fig. 1a, right). Dry direct-seeding is adopted in upland rice (Gupta and O'Toole 1986) and aerobic rice (Bouman et al. 2007). In the past decades, numerous researchers worldwide have dealt with yield performance and water use efficiency or water productivity (WP) of dry direct-seeded rice, but they reported variable yield response depending upon location and type of cultivar. Some studies have reported that more than $11.2 \mathrm{t} /$ ha grain yield was achieved in dry direct-seeded rice (Dong et al. 2005; Kato et al. 2009); Stevens et al. (2012) in a study conducted in Mossouri, USA, reported that dry direct-seeded rice reached $10.3 \mathrm{Mg} \mathrm{ha}^{-1}$ grain yield with $750 \mathrm{~mm}$ water input which was far below the water input in transplanted-flooded rice. In Japan, across various cultivars and locations, the average grain yield of dry direct-seeded rice was about $9.6 \mathrm{t} / \mathrm{ha}$ (Yun et al. 1997; Kato et al. 2009; Katsura and Nakaide 2011; Matsunami et al. 2009). In China, a grain yield of $8.4 \mathrm{t} / \mathrm{ha}$ with flush irrigation was reported in Jiangsu Province (Shi et al. 2001); Zhao et al. (2007) reported $5.33 \%$ higher grain yields and about $25-50 \%$ lower water use in dry direct-seeded rice than transplanted-flooded rice. Zhu (2008) documented that sowing of rice in dry direct-seeded rice system increased the grain yield by $22 \%$ and reduced the water input by $6000 \mathrm{~m}^{3} \mathrm{ha}^{-1}$ compared with transplanted-flooded rice. Input water savings of $35-57 \%$ have been reported for dry direct-seeded rice sown into non-puddled soil compared with continuously flooded (Sharma et al. 2002; Singh et al. 2002). Results of farmers' participatory trials suggested a small increase or $10 \%$ decline in yield of dry direct-seeded rice compared with transplanted-flooded rice, and around a $20 \%$ reduction in water requirement (Gupta et al. 2003). Kato and
Fig. 1 a: Soil preparation for dry direct-seeded rice $(l e f t)$ and for traditional transplanted-flooded rice (right); $\mathbf{b}$ water management in dry direct-seeded rice system, before irrigation (left) and after irrigation (right) $\mathbf{a}$
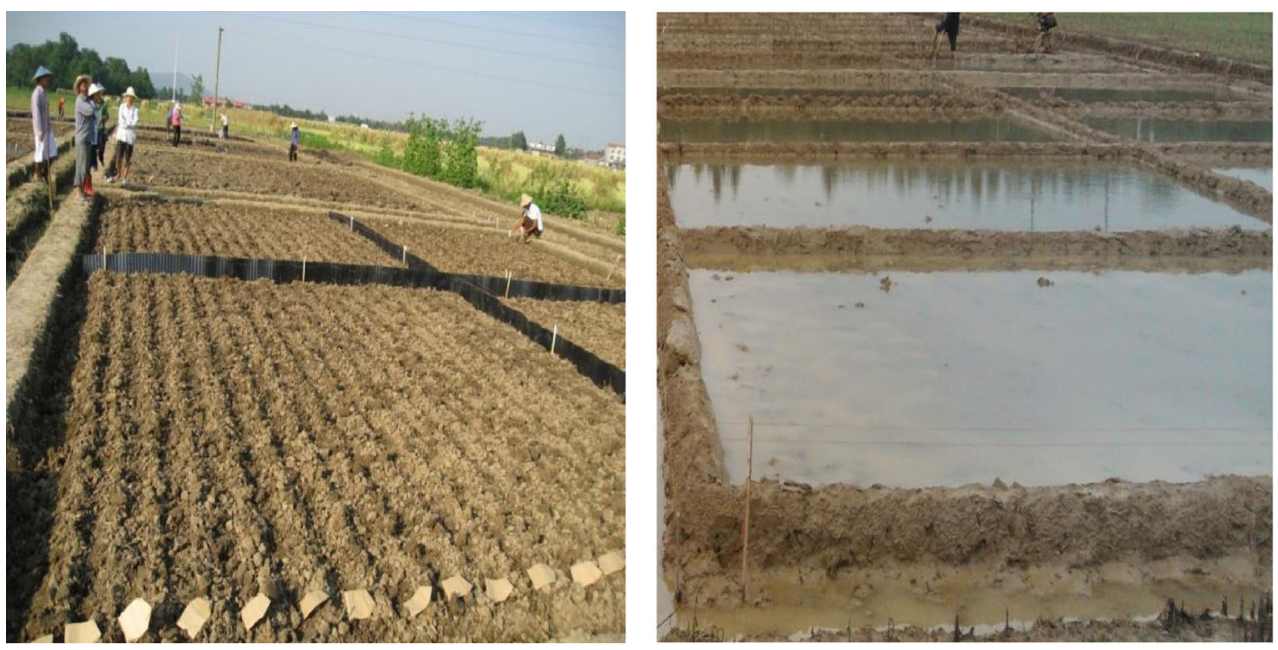

b

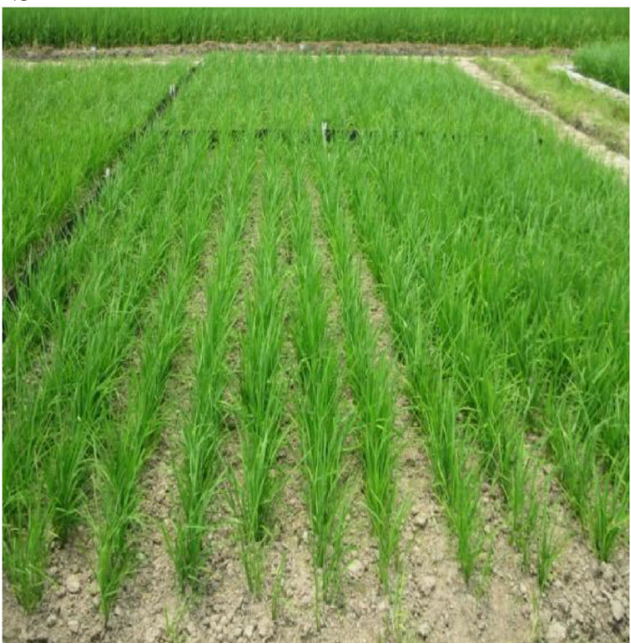

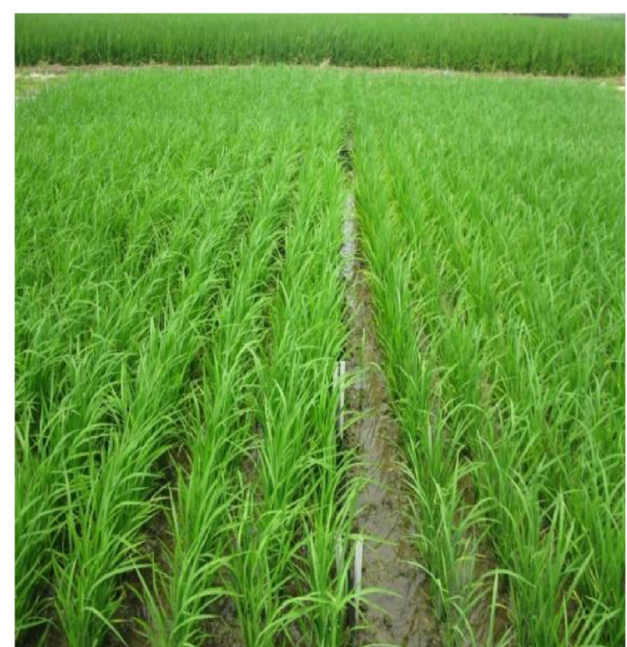


Katsura (2014) observed that WP in dry direct-seeded rice ranged from 0.59 to $1.37 \mathrm{~kg}_{\text {grain }} \mathrm{m}^{-3}$ water among different locations and irrigation schedules. They recorded different yield and WP because of varying environment and irrigation schedule. Nitrogen use efficiency in dry direct-seeded rice was also different from that in transplanted-flooded rice. With optimal water management, dry direct-seeded rice can achieve nitrogen use efficiency of over $80 \%$ (Wilson et al. 2000), much higher than that in transplanted-flooded rice (30-40 \%) (Zheng et al. 2007).

To date, plenty of work has been done on exploring yield performance, WP and nitrogen use efficiency of dry directseeded rice system based on aerobic soil conditions (both rainfed and control irrigation). Nonetheless, few studies have been conducted to unravel the crop performance and resource use efficiency in dry direct-seeded rice systems under anaerobic (flooded) soil conditions. Therefore, the present study was carried out in Central China (one of the largest riceplanting regions in China) aimed at estimating fthe easibility of dry direct-seeded rice kept under anaerobic conditions against transplanted-flooded rice on the basis of rice growth and yield performance and resource use efficiency.

\section{Materials and methods}

\subsection{Site description}

The present study was conducted at Zhougan Village (29 $51^{\prime}$ N, $\left.115^{\circ} 33^{\prime} E\right)$, Dajin Town, Wuxue County, Hubei Province, China, during the 2012 and 2013 growing seasons. The organic matter, total nitrogen $(\mathrm{N})$, available phosphorus, and potassium of upper $20 \mathrm{~cm}$ soil were $17.7 \mathrm{~g} \mathrm{~kg}^{-1}, 0.17 \%$, $30.4 \mathrm{mg} \mathrm{kg}^{-1}$, and $80.7 \mathrm{mg} \mathrm{kg}^{-1}$, respectively.

\subsection{Experimentation and data collection}

The proposed study was laid out in a randomized complete block design under split plot arrangements with four replications. Different planting patterns, viz., dry direct-seeded rice and transplanted-flooded rice, were assigned to main plots while three different indica cultivars (Lvhan1, Huanghuazhan, and Yangliangyou 6) with different growth durations (Table 2) were kept in subplots $(6 \mathrm{~m} \times 5 \mathrm{~m})$. Lvhan 1 is a typical drought $\mathrm{r}$-sistant inbred cultivar with short growth duration, while the inbred cultivar Huanghuazhan and hybrid cultivar Yangliangyou 6 are mega varieties and commonly grown by rice farmers in Central China.

In order to minimize the seepage losses, the main plots were separated with triple bunds to avoid flow of water between the dry direct-seeded rice and transplanted-flooded rice plots. All bunds were covered with plastic film installed to a depth of $20 \mathrm{~cm}$ below the soil surface. In the dry direct- seeded rice plots, dry seeds were sown manually during first week of May in both years keeping 25 -cm-wide rows. The soil in the dry direct-seeded rice plot was dry-ploughed and harrowed, without puddling. The seeding rate for each cultivar was $60 \mathrm{~kg} \mathrm{ha}^{-1}$. In the transplanted-flooded rice plots, pregerminated seeds were sown in a seedbed at the beginning of May. During soil preparation, $125 \mathrm{~mm}$ water was applied in the main plots with an area of $120 \mathrm{~m}^{2}$ for soil ploughing, harrowing and puddling in both years. Twenty-five-day-old seedlings were transplanted into the well-prepared paddy soil at the end of May in both years. Transplanting was done at a hill spacing of $25 \times 13.3 \mathrm{~cm}$ with three seedlings per hill. No irrigation was applied to the dry direct-seeded rice plots until the five-leaf stage; the plots before irrigation are shown in Fig. 1b, left. After the five-leaf stage, the water level was allowed to fluctuate between 5 and $10 \mathrm{~cm}$ during the whole rice-growing season (Fig. 1b, right), whereas, in the transplanted-flooded rice plots, a 1- to 3-cm water layer was kept during the first week after transplanting, and then the flooded water was kept at the same level with $5-$ to $10-\mathrm{cm}$ water depth for all plots. A flow meter installed in the irrigation pipelines was used to monitor the amount of irrigation water. Data regarding daily rainfall were recorded by a rain gauge located in the center of the experimental field. Total water use and WP were calculated based on water used for puddling during land preparation, irrigation and rainfall during the growing season.

A fertilizer dose of 150:40:00 kg N: $\mathrm{P}_{2} \mathrm{O}_{5}: \mathrm{K}_{2} \mathrm{O}$ ha ${ }^{-1}$ was applied equally to all treatments. The whole of the phosphorus pentoxide, $26 \%$ of the $\mathrm{N}$, and $50 \%$ of potassium oxide was applied as a starter basal dose, while residual $\mathrm{N}$ was equally split at the middle tillering stage and the panicle initiation stage, and $50 \%$ of the potassium was top-dressed at panicle initiation at a rate of $50 \mathrm{~kg} \mathrm{~K}_{2} \mathrm{O} \mathrm{ha}{ }^{-1}$. An amount of $\mathrm{Zn}$ $\left(5 \mathrm{~kg} \mathrm{ha}^{-1}\right)$ was also applied to the soil as starter dose. Weeds, diseases and insects were intensively controlled during the whole growing season in both years.

At maturity, $0.5 \mathrm{~m}^{2}$ ( 15 hills for transplanted-flooded rice and 10 sub-samples divided from $1 \mathrm{~m}$ along the adjacent two rows for dry direct-seeded rice) plants were sampled to determine yield components, aboveground total biomass and harvest index. Panicle number was counted in each sample to determine the panicle number per $\mathrm{m}^{2}$, and then plants were separated into straw and panicles. Through hand-threshing, all spikelets parted from the rachis were submerged into the tap water to separate the filled grains from the others. Further screening was completed by a winnowing cleanliness instrument (FJ-1; China Rice Research Institute, China) to separate the half-filled spikelets from the unfilled spikelets. Three subsamples of $30.0 \mathrm{~g}$ of filled spikelets, $2.0 \mathrm{~g}$ of unfilled spikelets, and all of the half-filled spikelets were taken to count the number of spikelets. After oven-drying at $70{ }^{\circ} \mathrm{C}$ to constant weight, dry weight of straw, rachis and filled, half-filled and 
unfilled spikelets were determined. Aboveground total dry weight is the summation of straw, rachis and all the spikelets. Spikelets per panicle, grain-filling percentage $(100 \times$ filled spikelets number/total spikelets number), and harvest index $(100 \times$ filled spikelets weight/aboveground total biomass $)$ were calculated. Grain yield was determined from a $5-\mathrm{m}^{2}$ area in each plot and adjusted to the standard moisture content of $0.14 \mathrm{~g} \mathrm{H}_{2} \mathrm{O} \mathrm{g}^{-1}$ fresh weight. WP $\left(\mathrm{kg} \mathrm{m}^{-3}\right)$ was calculated as the grain yield per unit total water input including water used for puddling, irrigation and rainfall during growing season. Tissue $\mathrm{N}$ concentration was determined by the $\mathrm{C} / \mathrm{N}$ analyzer (Vario Max CN, Hannau, Germany) to calculate the N content in grains and straw. Nitrogen use efficiency for grain production $\left(\mathrm{NUE}_{\mathrm{g}}\right)$ was calculated as the ratio of filled grain weight to total $\mathrm{N}$ uptake.

\subsection{Weather data}

Except for rainfall, other meteorological data were collected from a weather station (CR800; Campbell, USA) near the experimental field. Data collected included daily average temperature and solar radiation.

\subsection{Data analysis}

Data were analyzed to confirm its variability following analysis of variance using Statistix 8.0. The differences between treatments were separated using Least Significance Difference (LSD) test at 0.05 probability level in each year.

\section{Results and discussion}

\subsection{Weather conditions}

The weather data revealed that daily average temperature and solar radiation during the course of study was similar in 2012 and 2013 (Fig. 2). Nonetheless, data regarding rainfall and daily maximum temperature showed significant variations between 2 years, but it was not much different from the previous 10-year average (data not shown). Both the amount and frequency of rainfall during the rice growing season were higher in 2012 than in 2013 (Table 1; Fig. 2e, f). High temperature (daily maximum temperature $\geq 35^{\circ} \mathrm{C}$ ) occurred more frequently in 2013 (Fig. 2b) than 2012 (Fig. 2a).

\subsection{Irrigation and total water input}

Compared with transplanted-flooded rice, dry direct-seeded rice consumed 17.6, 14.9, and $15.4 \%$ less water (puddling, irrigation, and rainfall) in Lvhan1, Huanghuazhan, and Yangliangyou6, respectively, in 2012, and 16.0, 14.1, and $13.7 \%$ less water in 2013 (Table 1). Across the cultivars and years, dry direct-seeded rice used $15.3 \%$ less water than transplanted-flooded rice. In both years, rainfall in dry directseeded rice was comparable to that in transplanted-flooded rice. Rainfall during the whole growing season accounted for approximately 50 and $35 \%$ of total water input in 2012 and 2013, respectively. Additionally, accompanied by less irrigation times, the amount of irrigation in dry direct-seeded rice was always lower than transplanted-flooded rice in all cultivars (Table 1). Regardless of rainfall, and taking the water used for puddling into consideration, dry direct-seeded rice saved water up to $26 \%$ on average.

Compared with transplanted-flooded rice, dry directseeded rice with 4-5 fewer irrigations saved the water input and consequently reduced the labor cost. Bouman et al. (2002) reported that dry direct-seeded rice could save $50 \%$ of total water input, compared with transplanted-flooded rice. However, water saving in this study was not as high as reported by previous studies. This might be attributed to the anaerobic conditions and lack of hardpan in the dry directseeded rice field, which led to loss of water by seepage. Sudhir-Yadav et al. (2011) argued that seepage could result in the large amount of water use in dry direct-seeded rice, because it is one of primary ways to consume water in agriculture, especially in fields without puddling.

The data depicted that total water input with a low rainfall and a high irrigation in 2013 was significantly different from that in 2012. One reason is that high temperature increases the water evaporation, and the other is that the extra water is used to cool the crop population for counteracting extremely high temperatures. Cooling of crop plants by water usage in response to high temperature is important to avoid a yield penalty, as previous studies have reported that extremely high temperatures can lead to a huge yield loss (Mohammed and Tarpley 2011; Prasad et al. 2006).

3.3 Grain yield, water productivity and nitrogen use efficiency

Grain yield did not vary between the dry direct-seeded rice and transplanted-flooded rice across three cultivars in both years (Table 2). Nevertheless, the differences in panicle number per $\mathrm{m}^{2}$ between dry direct-seeded rice and transplantedflooded rice were significant and consistent across cultivars and years. On average, dry direct-seeded rice produced 28.6 and $19.5 \%$ more panicles per $\mathrm{m}^{2}$ than transplanted-flooded rice in 2012 and 2013, respectively. In contrast, the spikelets per panicle showed an opposite tendency with panicle number per $\mathrm{m}^{2}$. Across the cultivars, number of spikelets per $\mathrm{m}^{2}$ were 25.5 and $16.7 \%$ higher in transplanted-flooded rice than that in dry direct-seeded rice in 2012 and 2013, respectively, but the difference between cropping patterns were non-significant except in Huanghuazhan and Yangliangyou6 during 2012 (Table 2). There were inconsistent differences in grain weight and grain filling percentage between dry direct-seeded rice 
Temperature $\left({ }^{\circ} \mathrm{C}\right)$
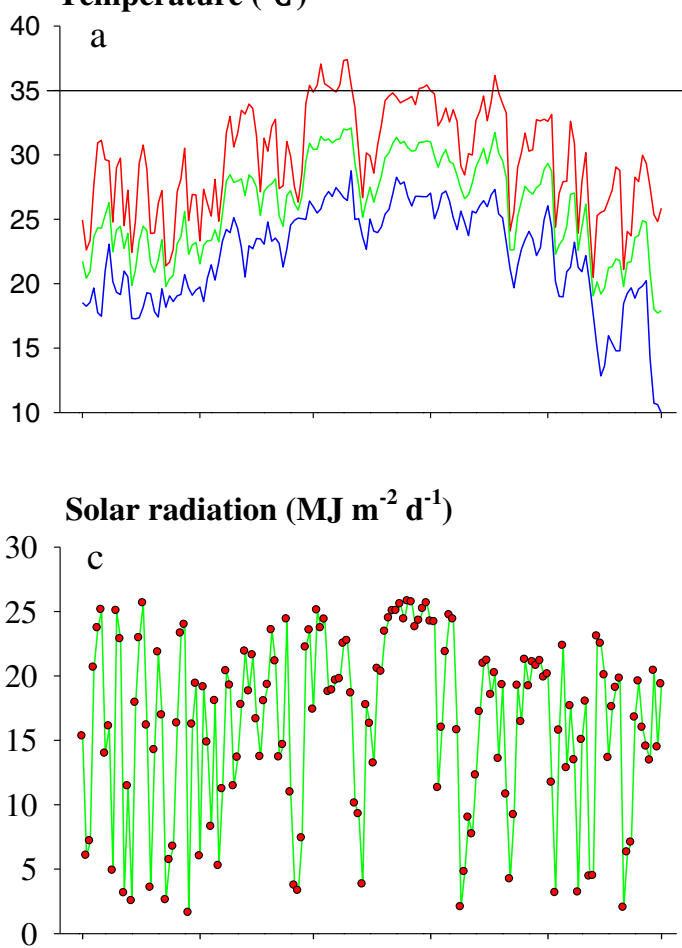

Rainfall (mm)

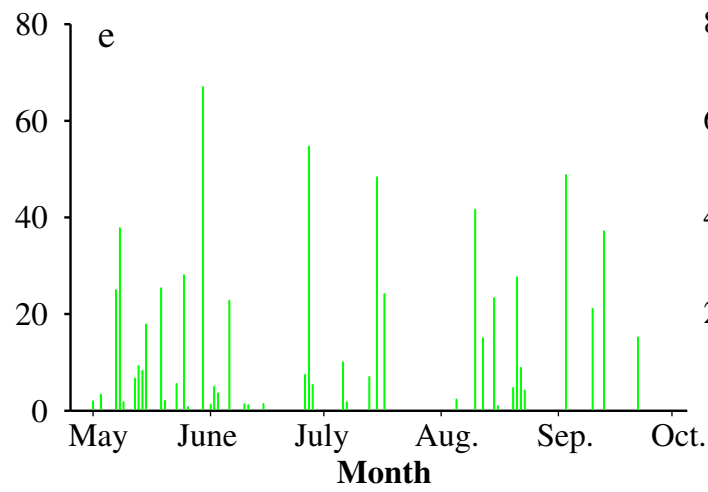

Temperature $\left({ }^{\circ} \mathrm{C}\right)$
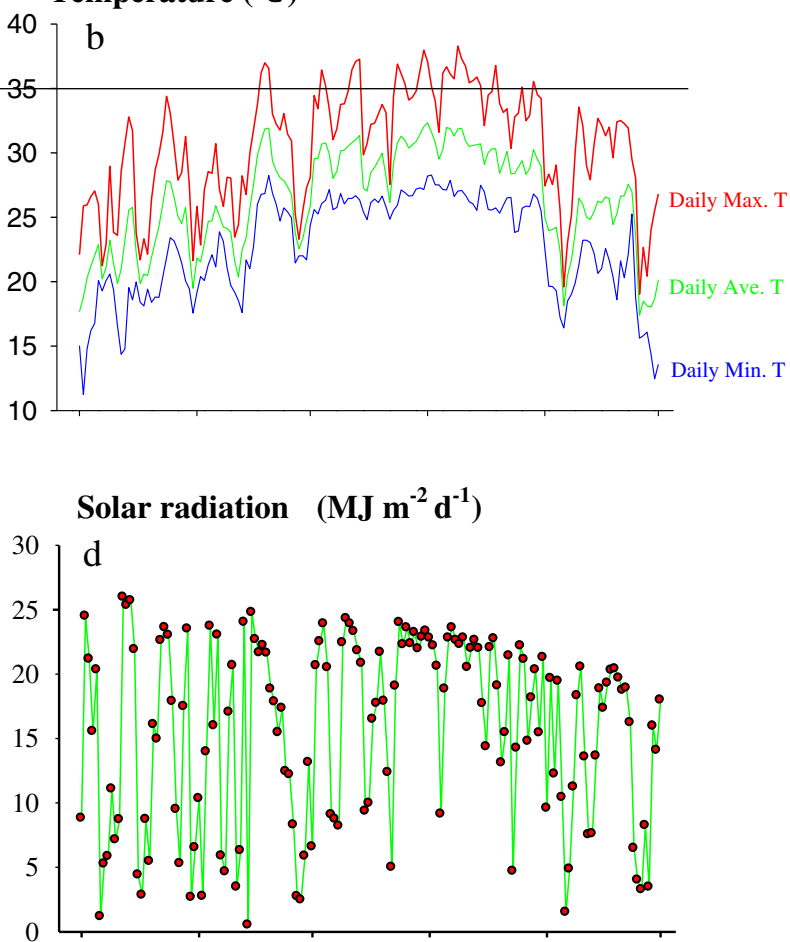

\section{Rainfall (mm)}

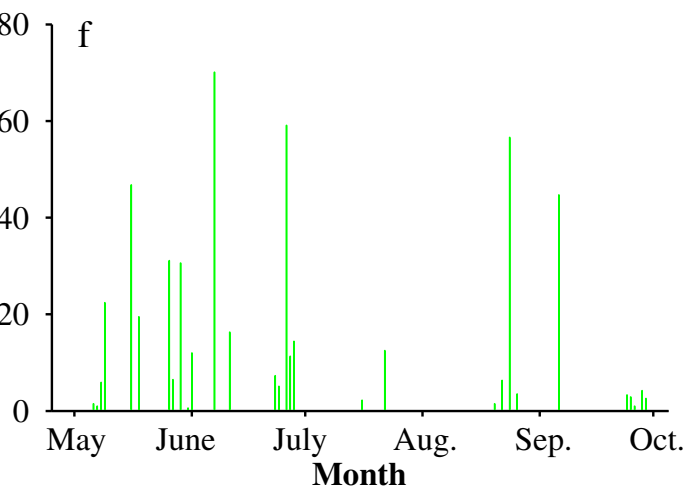

Fig. 2 Temperature (daily maximum, daily average and daily minimum), solar radiation and rainfall during the rice-growing season at Wuxue County, Hubei Province, China, in 2012 (a, c, e) and 2013 (b, d, f)

Table 1 Water input of three cultivars under dry direct-seeded rice (DSR) and traditional transplanted-flooded rice (TFR) conditions at Wuxue County, Hubei Province, China, in 2012 and 2013

\begin{tabular}{|c|c|c|c|c|c|c|c|c|c|c|c|}
\hline \multirow[t]{2}{*}{ Cultivar } & \multirow{2}{*}{$\begin{array}{l}\text { Establishment } \\
\text { method }\end{array}$} & \multicolumn{5}{|l|}{2012} & \multicolumn{5}{|l|}{2013} \\
\hline & & $\begin{array}{l}\text { Irrigation } \\
\text { times }\end{array}$ & $\begin{array}{l}\text { Puddling } \\
\text { (mm) }\end{array}$ & $\begin{array}{l}\text { Irrigation } \\
(\mathrm{mm})\end{array}$ & $\begin{array}{l}\text { Rainfall } \\
(\mathrm{mm})\end{array}$ & $\begin{array}{l}\text { Total water } \\
\text { input }^{\mathrm{a}}(\mathrm{mm})\end{array}$ & $\begin{array}{l}\text { Irrigation } \\
\text { times }\end{array}$ & $\begin{array}{l}\text { Puddling } \\
\text { (mm) }\end{array}$ & $\begin{array}{l}\text { Irrigation } \\
(\mathrm{mm})\end{array}$ & $\begin{array}{l}\text { Rainfall } \\
(\mathrm{mm})\end{array}$ & $\begin{array}{l}\text { Total water } \\
\text { input (mm) }\end{array}$ \\
\hline \multirow[t]{2}{*}{ Lvhan1 } & DSR & 13 & 0 & 456 & 454 & 910 & 11 & 0 & 659 & 376 & 1035 \\
\hline & TFR & 17 & 125 & 536 & 443 & 1104 & 16 & 125 & 731 & 376 & 1232 \\
\hline \multirow[t]{2}{*}{ Huanghuazhan } & DSR & 13 & 0 & 456 & 524 & 980 & 13 & 0 & 769 & 444 & 1214 \\
\hline & TFR & 17 & 125 & 536 & 489 & 1150 & 18 & 125 & 844 & 444 & 1413 \\
\hline \multirow[t]{2}{*}{ Yangliangyou6 } & DSR & 13 & 0 & 456 & 576 & 1032 & 13 & 0 & 769 & 489 & 1258 \\
\hline & TFR & 17 & 125 & 536 & 559 & 1220 & 18 & 125 & 844 & 489 & 1458 \\
\hline
\end{tabular}

${ }^{\mathrm{a}}$ Total water input=Puddling + Irrigation + Rainfall 
Table 2 Yield and yield components of three cultivars under dry direct-seeded rice (DSR) and traditional transplanted-flooded rice (TFR) conditions at Wuxue County, Hubei Province, China, in 2012 and 2013

\begin{tabular}{|c|c|c|c|c|c|c|c|c|c|c|}
\hline Cultivar & $\begin{array}{l}\text { Establishment } \\
\text { method }\end{array}$ & $\begin{array}{l}\text { Growth } \\
\text { duration } \\
\text { (day) }\end{array}$ & $\begin{array}{l}\text { Grain yield } \\
\left(\mathrm{Mg} \mathrm{ha}^{-1}\right)\end{array}$ & $\begin{array}{l}\text { Total biomass } \\
\left(\mathrm{Mg} \mathrm{ha}^{-1}\right)\end{array}$ & $\begin{array}{l}\text { Harvest } \\
\text { index }\end{array}$ & $\begin{array}{l}\text { Panicles } \\
\left(\mathrm{m}^{-2}\right)\end{array}$ & $\begin{array}{l}\text { Spikelets } \\
\text { per panicle }\end{array}$ & $\begin{array}{l}\text { Spikelets } \mathrm{m}^{-2} \\
(\times 1000)\end{array}$ & $\begin{array}{l}\text { Grain } \\
\text { filling } \\
(\%)\end{array}$ & $\begin{array}{l}\text { 1000-grain } \\
\text { weight }(\mathrm{g})\end{array}$ \\
\hline \multicolumn{11}{|l|}{2012} \\
\hline \multirow[t]{2}{*}{ Lvhan1 } & DSR & 105 & $8.71 \mathrm{a}$ & $16.56 \mathrm{a}$ & $0.49 \mathrm{~b}$ & $363 \mathrm{a}$ & $105.7 \mathrm{~b}$ & $38.2 \mathrm{a}$ & $86.8 \mathrm{~b}$ & $24.7 \mathrm{a}$ \\
\hline & TFR & 105 & $8.23 \mathrm{a}$ & $14.05 \mathrm{~b}$ & $0.54 \mathrm{a}$ & $255 \mathrm{~b}$ & $140.1 \mathrm{a}$ & $35.7 \mathrm{a}$ & $91.5 \mathrm{a}$ & $23.1 \mathrm{~b}$ \\
\hline \multirow[t]{2}{*}{ Huanghuazhan } & DSR & 116 & $9.73 \mathrm{a}$ & $17.34 \mathrm{a}$ & $0.51 \mathrm{a}$ & $369 \mathrm{a}$ & $144.1 \mathrm{~b}$ & $53.2 \mathrm{a}$ & $82.6 \mathrm{~b}$ & $20.2 \mathrm{a}$ \\
\hline & TFR & 116 & $9.24 \mathrm{a}$ & $17.81 \mathrm{a}$ & $0.49 \mathrm{a}$ & $317 \mathrm{~b}$ & $155.1 \mathrm{a}$ & $49.1 \mathrm{~b}$ & $88.2 \mathrm{a}$ & $20.1 \mathrm{a}$ \\
\hline \multirow[t]{2}{*}{ Yangliangyou6 } & DSR & 133 & $10.39 \mathrm{a}$ & $19.15 \mathrm{a}$ & $0.48 \mathrm{a}$ & $310 \mathrm{a}$ & $137.9 \mathrm{~b}$ & $42.7 \mathrm{~b}$ & $79.6 \mathrm{a}$ & $27.3 \mathrm{~b}$ \\
\hline & TFR & 133 & $10.56 \mathrm{a}$ & $19.99 \mathrm{a}$ & $0.49 \mathrm{a}$ & $244 \mathrm{~b}$ & $188.0 \mathrm{a}$ & $45.9 \mathrm{a}$ & $76.7 \mathrm{a}$ & $27.7 \mathrm{a}$ \\
\hline \multicolumn{11}{|l|}{2013} \\
\hline \multirow[t]{2}{*}{ Lvhan1 } & DSR & 104 & $6.77 \mathrm{a}$ & $13.29 \mathrm{a}$ & $0.47 \mathrm{a}$ & $281 \mathrm{a}$ & $98.2 \mathrm{~b}$ & $27.5 \mathrm{a}$ & $91.9 \mathrm{a}$ & $24.8 \mathrm{a}$ \\
\hline & TFR & 104 & $6.83 \mathrm{a}$ & $13.24 \mathrm{a}$ & $0.48 \mathrm{a}$ & $244 \mathrm{~b}$ & $117.0 \mathrm{a}$ & $28.4 \mathrm{a}$ & $91.7 \mathrm{a}$ & $24.3 \mathrm{~b}$ \\
\hline \multirow[t]{2}{*}{ Huanghuazhan } & DSR & 118 & $8.51 \mathrm{a}$ & $15.94 \mathrm{a}$ & $0.53 \mathrm{a}$ & $332 \mathrm{a}$ & $147.5 \mathrm{~b}$ & $49.0 \mathrm{a}$ & $86.4 \mathrm{~b}$ & $19.9 \mathrm{a}$ \\
\hline & TFR & 118 & $8.94 \mathrm{a}$ & $15.57 \mathrm{a}$ & $0.52 \mathrm{a}$ & $281 \mathrm{~b}$ & $165.6 \mathrm{a}$ & $46.4 \mathrm{a}$ & $88.8 \mathrm{a}$ & $19.5 \mathrm{a}$ \\
\hline \multirow[t]{2}{*}{ Yangliangyou6 } & DSR & 132 & $9.96 \mathrm{a}$ & $18.71 \mathrm{a}$ & $0.51 \mathrm{a}$ & $272 \mathrm{a}$ & $150.6 \mathrm{~b}$ & $40.8 \mathrm{a}$ & $83.7 \mathrm{a}$ & $27.7 \mathrm{a}$ \\
\hline & TFR & 132 & $10.25 \mathrm{a}$ & $17.73 \mathrm{a}$ & $0.52 \mathrm{a}$ & $217 \mathrm{~b}$ & $178.8 \mathrm{a}$ & $38.7 \mathrm{a}$ & $85.4 \mathrm{a}$ & $27.7 \mathrm{a}$ \\
\hline
\end{tabular}

Within a column for each cultivar in 1 year, means followed by the different letters are significantly different from each other at LSD (0.05)

and transplanted-flooded rice. Likewise, the total biomass and harvest index did not differ between dry direct-seeded rice and transplanted-flooded rice in both years, except for Lvhan1 in 2012. In this study, WP was significantly higher in dry directseeded rice as compared to transplanted-flooded rice. WP in dry direct-seeded rice ranged from 0.96 to 1.02 and from 0.70 to $0.79 \mathrm{~kg}$ grain $\mathrm{m}^{-3}$ water in 2012 and 2013, respectively. Total $\mathrm{N}$ content (grains and straw) was not significantly different among cultivars, and it was lower in dry direct-seeded rice than in transplanted-flooded rice (Table 3). The differences in $\mathrm{NUE}_{\mathrm{g}}$ between dry direct-seeded rice and transplanted-flooded rice were significant and consistent, except for Yangliangyou6 in 2013. Compared with transplanted-flooded rice, dry directseeded rice had 26.0, 10.4, and $24.5 \%$ higher NUE in 2012, and 12.9, 14.4, and $6.3 \%$ higher $\mathrm{NUE}_{\mathrm{g}}$ in 2013 in Lvhan1, Huanghuazhan, and Yangliangyou6, respectively.

Overall, dry direct-seeded rice production system can furnish comparable grain yield and greater resource use efficiency (WP and $\mathrm{NUE}_{\mathrm{g}}$ ) than transplanted-flooded rice (Fig. 3). The positive effect of dry direct-seeded rice system may be due to the increased root growth caused by the aerobic soil condition and slight drought stress at the early vegetative stage. Previous studies have shown that the aerobic soil condition can effectively increase tiller emergence and improve rhizosphere environment (Flessa and Fischer 1992), and slight drought stress in early stages can stimulate the root growth, thus improving the absorbing ability of root system before flooding (Kondo et al. 2000). Patrick et al. (1985) reported that the aerobic soil condition increased the amount of soil microorganisms which could increase the decomposition of organic matter and benefit the nutrient availability. In addition,
Yang et al. (2007) reported that water-saving irrigation could increase the root activity and nutrient absorbing ability.

Taking the advantage of more panicles per $\mathrm{m}^{2}$, grain yield of about $10.4 \mathrm{t} / \mathrm{ha}$ can be achieved in dry direct-seeded rice system which was comparable to that in transplanted-flooded rice. It demonstrated that, in terms of grain yield, dry directseeded rice can replace transplanted-flooded rice in Central China. However, there are still some differences on yield components between dry direct-seeded rice and transplantedflooded rice, which exist regarding panicles per $\mathrm{m}^{2}$ and spikelets per panicle (Table 2). Dry direct-seeded rice significantly increase the panicles per $\mathrm{m}^{2}$, and justified the previous study that higher panicles per $\mathrm{m}^{2}$ is the most important attribute for high yield (Peng et al. 2008; Tao et al. 2006). In present study, more number of panicles per $\mathrm{m}^{2}$ in direct-seeded rice mainly occurred due to larger numbers of plant per unit area. High seeding rate $\left(60 \mathrm{~kg} \mathrm{ha}^{-1}\right)$ in direct-seeded system resulted in more plant population in unit area that ultimately led to more number of panicles. Spikelets per panicle was negatively correlated with plant population, thus with a higher panicles per $\mathrm{m}^{2}$, spikelets per panicle of dry direct-seeded rice were lower than that in transplanted-flooded rice. While variations between dry direct-seeded rice and transplanted-flooded rice regarding other yield components did not show the same tendency with grain yield.

To prevent environment pollution caused by excessive use of $\mathrm{N}$ and tackle water crisis, reducing $\mathrm{N}$ and water inputs without yield loss has been the attractive approach for many years. Due to 29 days less flooding period in the whole growing season, the water requirement in dry direct-seeded rice was lower than that of transplanted-flooded rice (Table 3). 
Table 3 Flooding duration, water productivity $(W P)$, nitrogen content in grains and straw, and nitrogen use efficiency for grain production $\left(N U E_{\mathrm{g}}\right)$ of three cultivars under dry direct-seeded rice $(D S R)$ and traditional transplanted-flooded rice (TFR) conditions at Wuxue County, Hubei Province, China, in 2012 and 2013, respectively

\begin{tabular}{|c|c|c|c|c|c|c|c|c|c|c|c|}
\hline \multirow[t]{2}{*}{ Cultivar } & \multirow{2}{*}{$\begin{array}{l}\text { Establish-ment } \\
\text { method }\end{array}$} & \multicolumn{5}{|l|}{2012} & \multicolumn{5}{|l|}{2013} \\
\hline & & $\begin{array}{l}\text { Flooding } \\
\text { duration }\end{array}$ & $\begin{array}{l}\text { WP } \\
\left(\mathrm{kg} \mathrm{m}^{-3}\right)\end{array}$ & $\begin{array}{l}\mathrm{N} \text { content } \\
\text { in grains } \\
\left(\mathrm{kg} \mathrm{ha}^{-1}\right)\end{array}$ & $\begin{array}{l}\text { N content } \\
\text { in straw } \\
\left(\mathrm{kg} \mathrm{ha}^{-1}\right)\end{array}$ & $\begin{array}{l}\mathrm{NUE}_{\mathrm{g}}^{\mathrm{a}} \\
\left(\mathrm{kg} \mathrm{kg}^{-1}\right)\end{array}$ & $\begin{array}{l}\text { Flooding } \\
\text { duration }\end{array}$ & $\begin{array}{l}\text { WP } \\
\left(\mathrm{kg} \mathrm{m}^{-3}\right)\end{array}$ & $\begin{array}{l}\mathrm{N} \text { content } \\
\text { in grains } \\
\left(\mathrm{kg} \mathrm{ha}^{-1}\right)\end{array}$ & $\begin{array}{l}\mathrm{N} \text { content } \\
\text { in straw } \\
\left(\mathrm{kg} \mathrm{ha}^{-1}\right)\end{array}$ & $\begin{array}{l}\mathrm{NUE}_{\mathrm{g}} \\
\left(\mathrm{kg} \mathrm{kg}^{-1}\right)\end{array}$ \\
\hline \multirow[t]{2}{*}{ Lvhan1 } & DSR & 76 & $0.96 \mathrm{a}$ & $124.6 \mathrm{a}$ & $62.6 \mathrm{a}$ & $46.1 \mathrm{a}$ & 75 & $0.70 \mathrm{a}$ & $87.5 \mathrm{a}$ & $69.0 \mathrm{a}$ & $40.2 \mathrm{a}$ \\
\hline & TFR & 105 & $0.72 \mathrm{~b}$ & $131.3 \mathrm{a}$ & $65.9 \mathrm{a}$ & $36.6 \mathrm{~b}$ & 104 & $0.55 \mathrm{~b}$ & $95.6 \mathrm{a}$ & $82.2 \mathrm{a}$ & $35.6 \mathrm{~b}$ \\
\hline \multirow[t]{2}{*}{ Huanghuazhan } & DSR & 87 & $0.99 \mathrm{a}$ & $134.2 \mathrm{a}$ & $55.6 \mathrm{~b}$ & $47.7 \mathrm{a}$ & 89 & $0.70 \mathrm{a}$ & $105.1 \mathrm{a}$ & $64.6 \mathrm{a}$ & $51.5 \mathrm{a}$ \\
\hline & TFR & 116 & $0.80 \mathrm{~b}$ & $125.9 \mathrm{a}$ & $70.9 \mathrm{a}$ & $43.2 \mathrm{~b}$ & 118 & $0.63 \mathrm{~b}$ & $101.9 \mathrm{a}$ & $71.4 \mathrm{a}$ & $45.0 \mathrm{~b}$ \\
\hline \multirow[t]{2}{*}{ Yangliangyou6 } & DSR & 104 & $1.02 \mathrm{a}$ & $130.6 \mathrm{a}$ & $39.1 \mathrm{c}$ & $54.4 \mathrm{a}$ & 103 & $0.79 \mathrm{a}$ & $116.0 \mathrm{a}$ & $58.2 \mathrm{a}$ & $54.4 \mathrm{a}$ \\
\hline & TFR & 133 & $0.86 \mathrm{~b}$ & $147.7 \mathrm{a}$ & $79.7 \mathrm{ab}$ & $43.7 \mathrm{~b}$ & 132 & $0.70 \mathrm{~b}$ & $117.3 \mathrm{a}$ & $61.7 \mathrm{a}$ & $51.2 \mathrm{a}$ \\
\hline
\end{tabular}

Within a column for each cultivar in 1 year, means followed by different letters are significantly different from each other at LSD (0.05)

${ }^{\mathrm{a}} N U E_{g}$ grain yield per ha/ $(\mathrm{N}$ content in grains $+\mathrm{N}$ content in straw) per ha

Furthermore, WP in dry direct-seeded rice was significantly higher than that of transplanted-flooded rice. This result indicated that, consistent with other water-saving practices, dry direct-seeded rice could increase WP, but the positive effect was influenced by cultivars and the environment. However, 29 days of flooding period gap did not lead to a tremendous difference in water saving between dry direct-seeded rice and transplanted-flooded rice, the reason perhaps being that the hardpan in transplanted-flooded rice reduced the water loss from percolation, while, in the dry direct-seeded rice system, percolation was higher at the beginning of flooding.

Compared with transplanted-flooded rice, dry directseeded rice significantly increased $\mathrm{NUE}_{\mathrm{g}}$ in both years.
Contrary to Katsura et al. (2010), la arger rice population during the vegetative stage in dry direct-seeded rice did not lead to high $\mathrm{N}$ uptake, compared with transplanted-flooded rice. Ammonia volatilization before flooding (Qi et al. 2012) and serious seepage at the beginning of flooding (SudhirYadav et al. 2011) caused nutrient losses, which might be the most important reasons for low $\mathrm{N}$ uptake in dry directseeded rice. It suggests that the fertilizer should not be applied at tillering in dry direct-seeded rice to avoid the possibility of seepage occurring at the beginning of flooding. In this experiment, higher $\mathrm{NUE}_{\mathrm{g}}$ in dry direct-seeded rice might be due to higher $\mathrm{N}$ translocation from straw to grains, which indicates that rice plants in dry direct-seeded rice could use less $\mathrm{N}$ to
Fig. 3 Comparison of grain yield, water productivity $(W P)$ and nitrogen use efficiency for grain production $\left(N U E_{g}\right)$ between different establishment methods, dry direct-seeded rice $(D S R)$ and traditional transplanted-flooded rice $(T F R)$, across three cultivars and 2 years. Different letters above the bars mean that the difference between two bars is significant at LSD (0.05)

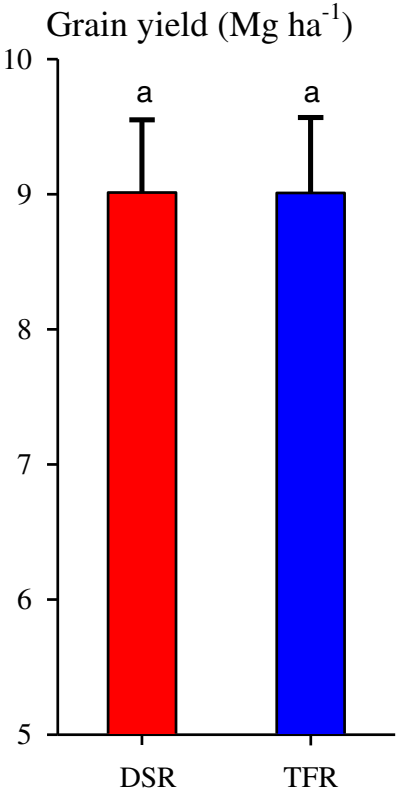

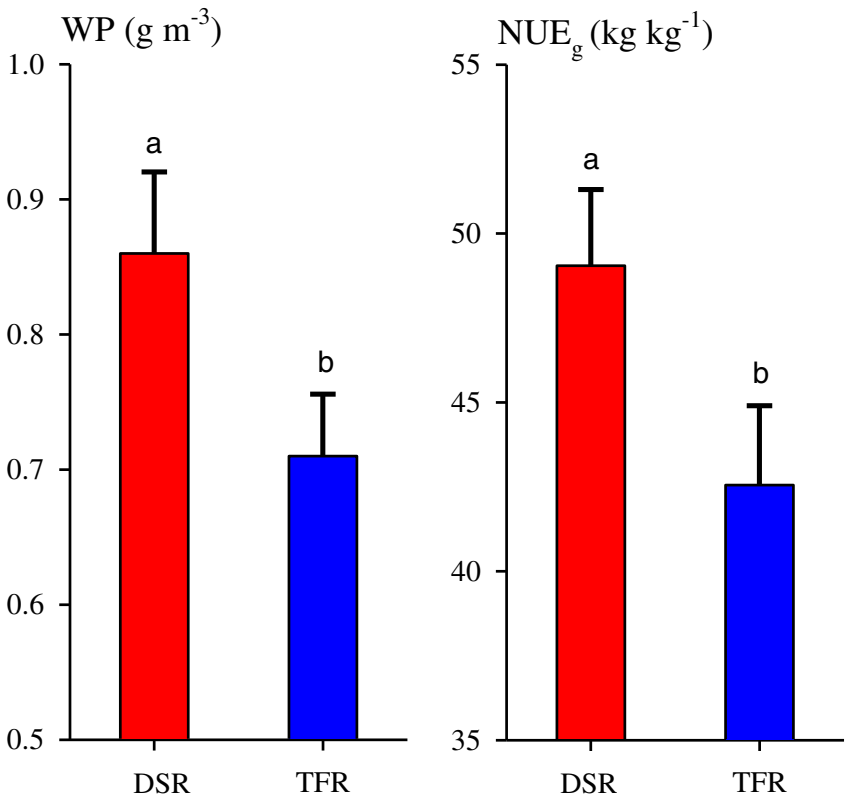

Establishment method 
produce more grains, compared with transplanted-flooded rice. Zhang et al. (2006) reported that total $\mathrm{N}$ uptake and $\mathrm{NUE}_{\mathrm{g}}$ were positively correlated with grain yield of rice. They suggested that, based on high total $\mathrm{N}$ uptake at maturity, it was important to improve $\mathrm{NUE}_{\mathrm{g}}$ to both increase yields and profit, and thus suitable for improving the cultivation and breeding in dry direct-seeded rice.

Considerable variations regarding yield and resource use efficiencies existed among cultivars. Super hybrid rice, "Yangliangyou6" with a high biomass accumulation, achieved the highest grain yield and WP in dry direct-seeded rice, while Lvhan1 with a low biomass accumulation achieved the lowest yield and WP in transplanted-flooded rice compared with the rest of the cultivars in both years. These results are consistent with those of Bouman et al. (2007), who reported that higher yield potential leads to higher WP. Crop maturity time also plays an important role in determining grain yield (Tirol-Padre et al. 1996). Inthapanya et al. (2000) reported that late maturing cultivars accumulated more $\mathrm{N}$, while in contrast, maturity had a negative effect on total nutrient content and grain yield. Our results are in accordance with these arguments. Yangliangyou6 as transplanted-flooded rice with the longest growth duration had the highest total biomass and total $\mathrm{N}$ uptake, while the shortest growth duration in Lvhan1 resulted in the lowest total biomass among the three varieties. Variation in $\mathrm{N}$ uptake among cultivars might be attributed to differences in nutrient uptake periods depending upon maturity time. All these indicated that the "super hybrid rice" Yangliangyou6 with higher yield potential and the inbred cultivar Huanghuazhan in the transplanting rice system can also perform well in dry direct-seeded rice systems. However, panicle size of Yangliangyou6 was much decreased in the dry direct-seeded rice system (Table 2).

The response of the rice crop significantly differed between the 2012 and 2013 growing seasons. Consistent with the difference of grain yield between the 2 years, panicles per $\mathrm{m}^{2}$, spikelets per $\mathrm{m}^{2}$, and total biomass in 2013 were also much lower than those in 2012, which could fully explain the yield decline in 2013. The reason for the lower yield in 2013 was the lower tiller number at the panicle initiation stage. The lower tiller number led to a lower leaf area index (LAI) which could subsequently result in the poor radiation interception and decreased biomass accumulation (Katsura et al. 2007). High temperature (daily maximum temperature $\geq 35{ }^{\circ} \mathrm{C}$ ) might be another reason for the lower yield in 2013 (Fig. 2b), because high temperatures inhibit photosynthesis and increase dark respiration (Turnbull et al. 2002), and can also up-regulate ethylene production (Hays et al. 2007), causing oxidative stress in the plants (Moeder et al. 2002). All these are unfavorable for biomass accumulation, leading to lower grain yield.

In our present study, the grain yield of dry direct-seeded flooded rice declined in 2013; however, such a decline was minimal as compared with the findings of Kreye et al (2009), who reported severe yield decline under monocropping in dry direct-seeded aerobic rice. We also found yield decline in transplanted-flooded rice in our study, which showed that the climatic variation, especially maximum daily high temperature, was responsible for the yield decline in both establishment methods. The yield decline of dry direct-seeded flooded rice did not reflect the influence of continuous cropping in the present study, suggesting the yield stability of this cropping system. However, long-term studies are inevitable to get sound conclusions regarding the yield trend of the dry direct-seeded flooded rice system.

In dry direct-seeded flooded rice, demand of water and labor input were lower, while WP and $\mathrm{NUE}_{\mathrm{g}}$ were higher than transplanted-flooded rice, which justifies its feasibility in terms of eco-efficient resource management. Although greenhouse gas emissions were not investigated in the present study, yet there was a 29-day shorter flooding duration in the dry direct-seeded rice as compared to the transplanted-flooded rice could predict less $\mathrm{CH}_{4}$ emission, and may also reduce $\mathrm{N}_{2} \mathrm{O}$ emission as compared to aerobic rice. Furthermore, flooding in the direct-seeded rice system will also lower the weed burden, which will ultimately reduce the use of pesticides. All these illustrate that dry direct-seeded flooded rice would be more competitive to mitigate the threat on resources and the environment in the near future.

\section{Conclusion}

Dry direct-seeded rice is a sustainable and very feasible alternative to TPR in Central China, based on comparable yield performance and higher resource use efficiencies. Without sprout cultivation and transplanting, it consumed less irrigation water and demands less labor, thus reducing the total inputs. Comparable rice yield in the dry direct-seeded rice system and low input demand justifies the higher output to input ratio. In addition, compared with transplanted-flooded rice, the higher $\mathrm{NUE}_{\mathrm{g}}$ and lower total $\mathrm{N}$ uptake in dry directseeded rice illustrated that improved $\mathrm{N}$ uptake of rice plants through cultivation and breeding can make a further increase in grain yield of dry direct-seeded rice. The Yangliangyou6 breed appeared superior to the rest of the varieties regarding its performance on yield, WP, and $\mathrm{NUE}_{\mathrm{g}}$, and can be successfully used in dry direct-seeded rice culture.

However, the evaluation of yield and resource use efficiency was limited by time and space, thus overall evaluation needs multi-location-multi-year experiments. Furthermore, evaluations regarding integrated economic efficiency and ecological benefits of dry direct-seeded flooded rice are required. In addition, there is need to study soil ecology in dry directseeded rice culture and develop site-specific production technologies for dry direct-seeded rice. 
Acknowledgments This work is supported by the National Natural Science Foundation of China (Project No. 31371571), the Open Project Program of Key Laboratory of Crop Ecophysiology and Farming System, Ministry of Agriculture (Project No. 201301), the National Science \& Technology Pillar Program (2013BAD20B06), and the Fundamental Research Funds for the Central Universities (Project No. 2013PY109).

\section{References}

Bouman BAM, Wang H, Yang X, Zhao J, Wang C (2002) Aerobic rice (Han Dao): a new way of growing rice in water-short areas. In: Proceedings of the 12th International Soil Conservation Organization Conference, 26-31 May, 2002, Beijing, China. Tsinghua University Press, pp. 175-181

Bouman BAM, Humphreys E, Tuong TP, Barker R (2007) Rice and water. Adv Argon 92:187-237. doi:10.1016/S0065-2113(04)92004-4

Cai H, Chen Q (2000) Rice research in China in the early 21st century. Chin Rice Res Newsl 8:14-16

Chauhan BS, Opeña J (2012) Effect of tillage systems and herbicides on weed emergence, weed growth, and grain yield in dry-seeded rice systems. Field Crop Res 137:56-69. doi:10.1016/j.fcr.2012.08.016

Coats B (2003) Global rice production. In: Smith CW, Dilday RH (eds) Rice origin, history, technology and production. Wiley, Hoboken, pp 247-470

Dong WZ, Ji MR, Yuan DM, Mao WQ (2005) $750 \mathrm{~kg}$ Yield target techniques by non-flooding irrigation and direct-sowing cultivation. China Rice 3:33

FAOSTAT (2011) FAO Statistical databases. www.fao.org. Food and Agriculture Organization (FAO) of the United Nations, Rome

Farooq M, Siddique KHM, Rehman H, Aziz T, Lee DJ, Wahid A (2011) Rice direct seeding: experiences, challenges and opportunities. Soil Till Res 111:87-98. doi:10.1016/j.still.2010.10.008

Flessa H, Fischer WR (1992) Plant-induced changes in the redox potentials of rice rhizospheres. Plant Soil 143(1):55-60. doi:10.1007/ BF00009128

Gupta PC, O'Toole JC (1986) Upland rice-a global perspective. IRRI, Manila

Gupta RK, Naresh RK, Hobbs PR, Jiaguo Z, Ladha JK (2003) Sustainability of post-green revolution agriculture: the rice-wheat cropping systems of the Indo-Gangetic Plains and China. In: Ladha JK, Hill JE, Duxbury JM, Gupta RK, Buresh RJ (eds) Improving the productivity and sustainability of rice-wheat systems: issues and impactsAmerican Society of Agronomy. Wisconsin, pp 1-25

Hays D, Do J, Mason R, Morgan G, Finlayson S (2007) Heat stress induced ethylene production in developing wheat grains induces kernel abortion and increased maturation in a susceptible cultivar. Plant Sci 172:1113-1123. doi:10.1016/j.plantsci.2007.03.004

Inthapanya P, Sipaseuth P, Sihavong V, Sihathep M, Chanphengsay S, Fukai J, Basnayake J (2000) Genotype differences in nutrient uptake and utilization for grain yield production of rainfed lowland rice under fertilised and non-fertilised conditions. Field Crop Res 65:5768. doi:10.1016/0378-4290(99)00070-X

IRRI (2002) Rice almanac: source book for the most important economic activity on earth. CABI, Wallingford

Kato Y, Katsura K (2014) Rice Adaptation to Aerobic Soils: Physiological Considerations and Implications for Agronomy. Plant Prod Sci (in press)

Kato Y, Okami M, Katsura K (2009) Yield potential and water use efficiency of aerobic rice (Oryza sativa L.) in Japan. Field Crop Res 11(3):328-334. doi:10.1016/j.fcr.2009.06.010

Katsura K, Nakaide Y (2011) Factors that determine grain weight in rice under high-yielding aerobic culture: the importance of husk size. Field Crop Res 123:266-272. doi:10.1016/j.fcr.2011.05.023
Katsura K, Maeda S, Horie T, Shiraiwa T (2007) Analysis of yield attributes and crop physiological traits of Liangyoupeijiu, a hybrid rice recently bred in China. Field Crop Res 103:170-177. doi:10. 1016/j.fcr.2007.06.001

Katsura K, Okami M, Mizunuma H, Kato Y (2010) Radiation use efficiency, $\mathrm{N}$ accumulation and biomass production of highyielding rice in aerobic culture. Field Crop Res 117:81-89. doi:10. 1016/j.fcr.2010.02.006

Kondo M, Maddala VR, Murty MVR, Aragones DV (2000) Characteristics of root growth and water uptake from soil in upland rice and maize under water stress. Soil Sci Plant Nutr 46(3):721732. doi:10.1080/00380768.2000.10409137

Kreye C, Bouman BAM, Castañeda A, Lampayan R, Faronilo J, Lactaoen A, Fernandez L (2009) Possible causes of yield failure in tropical aerobic rice. Field Crop Res 111:197-206. doi:10.1016/j.fcr.2008.12.007

Kumar V, Ladha JK (2011) Direct seeding of rice: recent developments and future research needs. Adv Agron 111:297-413

Liu J, Diamond J (2005) China's environment in a globalizing world. Nature 435:1179-1186. doi:10.1038/4351179a

Matsunami M, Matsunami T, Kokubun M (2009) Growth and yield of new rice for Africa (NERICAs) under different ecosystems and nutrient levels. Plant Prod Sci 12:381-389. doi:10.1626/pps.12.381

McDonald AJ, Riha SJ, Duxbury JM, Steenhuis TS, Lauren JG (2006) Soil physical responses to novel rice cultural practices in the ricewheat system: comparative evidence from a swelling soil in Nepal. Soil Tillage Res 86:163-175. doi:10.1016/j.still.2005.02.005

Moeder W, Barry C, Tauriainen A, Betz C, Tuomainen J, Utriainen M, Grierson D, Sandermann H, Langebartels C, Kangasjärvi J (2002) Ethylene synthesis regulated by bi-phasic induction of ACC synthase and ACC oxidase genes is required for $\mathrm{H}_{2} \mathrm{O}_{2}$ accumulation and cell death in ozone-exposed tomato. Plant Physiol 130:19181926. doi:10.1104/pp.009712

Mohammed AR, Tarpley L (2011) Effects of night temperature, spikelet position and salicylic acid on yield and yield-related parameters of rice (Oryza sativa L.) plants. J Agron Crop Sci 197:40-49. doi:10. 1111/j.1439-037X.2010.00439.x

Patrick W H, Mikkelsen, Duane S, Wells BR (1985) Plant nutrient behavior in flooded soil. In: Engelstad OP (ed) Fertilizer technology and use.Soil Science Society of America, Madison, pp 197-228

Peng S, Gurdev S, Khush VP, Tang Q, Zou Y (2008) Progress in ideotype breeding to increase rice yield potential. Field Crop Res 108:32-38. doi:10.1016/j.fcr.2008.04.001

Peng S, Tang Q, Zou Y (2009) Current status and challenges of rice production in china. Plant Prod Sci 12:3-8. doi:10.1626/pps.12.3

Prasad PVV, Boote KJ, Allen LHJ, Sheehy JE, Thomas JMG (2006) Species, ecotype and cultivar differences in spikelet fertility and harvest index of rice in response to high temperature stress. Field Crop Res 95:398-411. doi:10.1016/j.fcr.2005.04.008

Qi X, Wu W, Peng S, Shah F, Huang J, Cui K, Liu H, Nie L (2012) Ammonia volatilization from urea application influenced germination and early seedling growth of dry direct-seeded rice. Sci World J: 857472. doi: $10.1100 / 2012 / 857472$

Sharma PK, Bhushan L, Ladha JK, Naresh RK, Gupta RK, Balasubramanian BV, Bouman BAM (2002) Crop-water relations in rice-wheat cropping under different tillage systems and watermanagement practices in a marginally sodic, medium-textured soil. Water-wise rice production. International Rice Research Institute, Los Baños, pp 223-235

Sharma PK, Ladha JK, Bhushan L (2003) Soil physical effects of puddling in rice-wheat cropping systems. In: Ladha JK, Hill JE, Duxbury JM, Gupta RK, Buresh RJ (eds.) "Improving the Productivity and Sustainability of Rice-Wheat Systems: Issues and Impacts" ASA Special Publication, Madison, pp:97-113

Shi Y, Shen QR, Mao ZS, Li W (2001) Biological response of rice crop cultivated on upland soil condition and the effect of mulching on it. Plant Nutr Fert Sci 7(3):271-277 (In Chinese with English abstract) 
Singh AK, Choudhury BU, Bouman BAM (2002) Effects of rice establishment methods on crop performance, water use, and mineral nitrogen. Water-wise rice production. International Rice Research Institute, Los Baños, pp 237-246

Stevens G, Vories E, Heiser J, Rhine M (2012) Experimentation on cultivation of rice irrigated with a center pivot system. In: Lee TS (ed) Irrigation systems and practices inchallenging environments, InTech, Rijeka,Croatia, pp 233-254

Sudhir-Yadav G, Humphreys GE, Kukal SS, Walia US (2011) Effect of water management on dry seeded and puddle transplanted rice. Part 1. Crop performance. Field Crop Res 120:112-122. doi:10.1016/j. fcr.2010.09.002

Tao H, Brueck H, Dittert K, Kreye C, Lin S, Sattelmacher B (2006) Growth and yield formation of ricez (Oryza sativa L.) in the watersaving ground cover rice production system (GCRPS). Field Crop Res 95:1-12. doi:10.1016/j.fcr.2005.01.019

Tirol-Padre A, Ladha JK, Singh U, Laureles E, Punzalan G, Akita S (1996) Grain yield performance of rice genotypes at suboptimal levels of soil $\mathrm{N}$ as affected by $\mathrm{N}$ uptake and utilization efficiency. Field Crop Res 46:127-142. doi:10.1016/0378-4290(95)00095-X

Tuong TP, Bouman BAM (2003) Rice production in water-scarce environments. In: Proc Water Productivity Workshop, 12-14 November 2001, Colombo, Sri Lanka. International Water Management Institute, Colombo, Sri Lanka

Turnbull M, Murthy R, Griffin K (2002) The relative impacts of daytime and night-time warming on photosynthetic capacity in Populus deltoides. Plant Cell Environ 25:1729-1737. doi:10.1046/j. 1365-3040.2002.00947.x

Wilson C, Slaton N, Norman R, Miller D (2000) Efficient Use of Fertiliser. In: Rice Production Handbook, University of Arkansas, Division of Agriculture, Cooperative Extension Service, Chapter 8, pp:51-74

Yang J, Liu K, Wang Z, Du Y, Zhang J (2007) Water-saving and highyielding irrigation for lowland rice by controlling limiting values of soil water potential. J Integr Plant Biol 49:1445-1454. doi:10.1111/ j.1672-9072.2007.00555.x

Yun SI, Wada Y, Maeda T, Miura K, Watanabe K (1997) Growth and yield of japonica $\times$ indica hybrid cultivars under direct seeding and upland cultivation conditions. Jpn J Crop Sci 66:386-393

Zhang Y, Wang Y, Zhang C, Dong G, Yang L, Huang J, Chen P, Gong K (2006) Differences of Nitrogen Absorption and Utilization and Their Influences on Grain Yield of Conventional Indica Rice Cultivars. Jiangsu J Agr Sci 22:318-324. doi: 1000-4440(2006)04-0318-07. (In Chinese with English abstract)

Zhao C, Jiang H, Ren C, Yin Y, Li Y (2007) Studies on key techniques of sowing rice directly on dry land for high yield and high efficiency. J Jilin Agr Sci 32:9-11 (In Chinese with English abstract)

Zheng Y, Ding Y, Wang Q, Li G, Wu H, Yuan Q, Wang H, Wang S (2007) Effect of nitrogen applied before transplanting on NUE in rice. Agr Sci China 6:842-848 (In Chinese with English abstract)

Zhu L (2008) A report on dry direct seeding cultivation technique of early rice. J Guangxi Agr 23:10-11 (In Chinese with English abstract) 